DOI

\title{
АНАТОМІЧНА ЛЕКЦІЯ ЯК ВАЖЛИВИЙ ЗАСІБ ФОРМУВАННЯ КОРПОРАТИВНОЇ АКАДЕМІЧНОЇ КУЛЬТУРИ
}

\author{
В. Г. Черкасов, Л. І. Остапюк, І. В. Дзевульська, О. І. Ковальчук \\ Національний медичний університет імені О. О. Богомольця, м. Київ
}

\section{ANATOMICAL LECTURE AS AN IMPORTANT MEANS OF CORPORATE ACADEMIC CULTURE}

\author{
V. H. Cherkasov, L. I. Ostapyuk, I. V. Dzevulska, O. I. Kovalchuk \\ National Medical University by O. O. Bohomolets, Kyiv
}

\begin{abstract}
У статті проведений аналіз лекції з анатомії людини з позицій ії дидактичних функцій, формування кінцевої мети, якісної підготовки матеріалів до лекційних навчальних занять і структурування лекційного матеріалу відповідно до сучасних психолого-педагогічних вимог.

In the article the analysis lecture on Human Anatomy from the standpoint of its didactic function, forming the ultimate goal, quality training materials for lecture classes and lectures structured according to modern psychological - pedagogical requirements was made.
\end{abstract}

Вступ. Важливим принципом державної політики у сфері вищої освіти є інтеграція системи вищої освіти України у Європейський освітній простір, подальше упровадження Європейської кредитнотрансферної накопичувальної системи (ЄKTC) за умови збереження і розвитку досягнень та прогресивних традицій національної вищої школи [1].

Головним постулатом організації навчального процесу на кафедрі анатомії людини, як базовому структурному підрозділі, є його відповідність вимогам системи внутрішнього та зовнішнього забезпечення якості, а також орієнтація на кращі вітчизняні та світові зразки, врахування нової парадигми навчально-виховного процесу:

- суб’єктно-суб'єктні (взаємно відповідальні за результат) відносини між викладачами і студентами;

- орієнтація викладання дисципліни на конкретні результати навчання: що має знати, розуміти та вміти виконувати студент;

- студентоцентрований підхід в організації навчального процесу: заохочення та підтримка студентів, допомога їм у виробленні власних стилів та набуття досвіду навчання, вміння самоорганізуватись [2].

Упродовж останніх двох десятиріч вищі медичні навчальні заклади України готують лікарів за новими навчальними планами, що, значною мірою, відповідають вимогам європейських медичних уні- верситетів. У цих планах суттєво зменшене тижневе аудиторне навантаження студента (з 30 до 25 навчальних годин) і, відповідно, збільшена кількість годин на самостійну позааудиторну роботу студентів та зменшена кількість навчальних годин 3 дисциплін. В цих умовах особливого значення набуває лекція, яка відрізняється своєю часовою економічністю, можливістю акумулювати та надати студентам великий обсяг навчально-наукової інформації з навчальної дисципліни. Важливе місце займає лекційне викладання у програмах підготовки лікарів в європейських медичних школах Лідса (Великобританія), Утрехта (Нідерланди), Гранади (Іспанія), Мілана (Італія), з якими НМУ ім. О. О. Богомольця впродовж 4-х років успішно співпрацював у межах виконання міжнародного проекту TempusMumeena “Модернізація додипломної медичної освіти в країнах Східного сусідства Європейського Союзу”[3].

Закон України “Про вищу освіту” (2014) визначає лекцію одним із основних видів навчальних занять [1]. Сучасні науково-методичні видання підкреслюють важливе місце лекції серед інших форм організації освітнього процесу і дають їй таке визначення: “Навчальна лекція (лат. lectio - читання) - логічно завершений, науково обгрунтований, послідовний і систематизований виклад певного наукового або

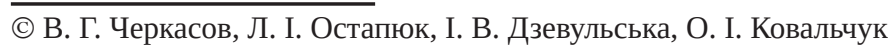


науково-методичного питання, теми чи розділу навчального предмета, ілюстрований, за необхідності, наочністю та демонструванням дослідів” [4].

У дидактиці лекція, як і практичні заняття, розглядається як важливий засіб керування навчальнопізнавальною діяльністю студентів для розв’язання освітніх завдань, визначених Стандартами вищої освіти, типовою та робочою навчальними програмами з навчальних дисциплін.

Основна частина. Кафедра анатомії людини Національного медичного університету імені О. О. Богомольця, визначена Міністерством охорони здоров’я України опорною серед інших однопрофільних кафедр, є розробником типових навчальних програм 3 навчальної дисципліни “Анатомія людини” для студентів медичних, стоматологічного, медико-психологічного та фармацевтичного факультетів. Теми лекцій відповідають структурній побудові навчального матеріалу у типових i робочих навчальних програмах i тісно пов’язані з тематично-календарними планами практичних занять відповідних семестрів. Лекційні та практичні заняття з анатомії людини мають особливе значення, оскільки саме з них студенти розпочинають своє професійне становлення. Зважаючи на це, кафедрою розроблені деталізовані методичні рекомендації для студентів щодо самопідготовки до навчальних занять.

Лекція з анатомії людини виконує ряд важливих дидактичних функцій:

- стимулювальна, мотиваційна (спрямована на пробудження інтересу до вивчення відповідних розділів анатомії людини, що є підгрунтям для подальшого вивчення ряду фундаментальних та клінічних дисциплін);

- інформаційна (передбачає передавання адаптованої для студентів інформації, отриманої лектором з різних літературних джерел; зміст інформації повинен відповідати програмі навчальної дисципліни);

- роз'яснювальна (передбачає трактування варіантів мінливості органів, вади їх розвитку, пов’язані з особливостями пренатального та раннього постнатального онтогенезу, а також під впливом екологічних факторів, тощо);

- систематизуюча (передбачає структурування навчального матеріалу з акцентом на взаємозалежність і єдність будови та функцій органів, систем органів, організму в цілому людини);

- переконувальна (полягає у використанні аргументованої логічної доказовості з використанням сучасних наукових морфологічних досягнень, 3 метою формування у студентів наукових поглядів);

- виховна та розвивальна (направлена на активізацію мислення слухачів, розвиток уяви, пам’яті та інших пізнавальних здібностей, на формування емоційної, естетичної і мовленнєвої культури).

Кінцева мета лекцій і практичних занять 3 анатомії людини - сприяти засвоєнню дисципліни та формуванню умінь, викладених у базовому [5] підручнику “Анатомія людини. У трьох томах”, який визначений нарадою завідувачів кафедр анатомії людини медичних університетів і академій України у 2010 році як “Єдиний національний підручник з анатомії людини ВМНЗ IV рівня акредитації”, відповідно до вимог Галузевих стандартів з вищої освіти:

- аналізувати інформацію про будову тіла людини, системи, що його складають, органи, тканини, клітини;

- визначати топографо-анатомічні взаємовідносини органів і систем людини;

- трактувати закономірності пренатального та раннього постнатального розвитку органів людини, варіанти мінливості органів, вади розвитку;

- інтерпретувати статеві, вікові та індивідуальні особливості будови організму людини;

- передбачати взаємозалежність і єдність структур та функцій органів людини, їх мінливість під впливом екологічних факторів;

- визначити вплив соціальних умов та праці на розвиток і будову організму людини;

- демонструвати володіння морально-етичними принципами ставлення до живої людини та її тіла як до об’єкта анатомічного та клінічного дослідження.

Кожна лекція з анатомії людини має конкретну освітню (навчальну) мету та дидактичну мету, що залежить від різних видів лекцій (вступна, тематична, настановча, оглядова) та від способу викладання навчального матеріалу під час лекції: інформаційна лекція, проблемна лекція, лекція-візуалізація, бінарна лекція, лекція із заздалегідь запланованими помилками, лекція-консиліум або конференція, лекція-бесіда, лекція-дискусія тощо.

Дидактична мета лекцій з анатомії:

- розвиток мотивації у студентів до вивчення певного розділу анатомії людини, зважаючи на важливість цих знань у подальшому вивченні інших розділів та в опануванні інших дисциплін, а також у професійному становленні лікаря; 
- створення умов для розвитку особистості студента, розуміння, осмислення, узагальнення та систематизації змісту навчального матеріалу лекції, передбаченого програмою з дисципліни;

- надання студентам методичних настанов щодо успішного оволодіння на практичних заняттях системою знань відповідного розділу дисципліни, що тематично пов’язаний з лекцією.

Важливою дидактичною метою лекції є також закладання фундаменту для формування компетенцій під час викладання анатомії людини на практичних заняттях.

Лекція з анатомії людини за методом викладу навчального матеріалу може бути класифікована як інформаційно-проблемна лекція-візуалізація з використанням елементів інтерактивного навчання для зворотного зв’язку з аудиторією.

Колектив лекторів кафедри анатомії людини приділяє значну увагу підготовці матеріалів до лекційних навчальних занять з урахуванням сучасних методологічних і методичних вимог до їх побудови. Кожен лектор готує опорний конспект як структурно-логічну схему короткого викладу навчального матеріалу відповідно до теми та плану лекції, які щорічно доповнюються новими науковонавчальними матеріалами. Фактично опорний конспект лекцій є її розширеними тезами. Дидактична сутність опорного конспекту полягає у включенні до нього короткого опису тематичного лекційного матеріалу за планом лекції, що корелює з питаннями підсумкового модульного контролю. Таким чином, опорний конспект лекцій як матеріальний носій навчальної інформації відображає основний зміст лекції, порядок викладу навчального матеріалу та логічно побудовані взаємозв'язки між його блоками, а також включає перелік конкретних засобів унаочнення, що допомагає на лекції глибше розкрити суть питань: слайди, таблиці, муляжі, анатомічні препарати, в т. ч. 3 анатомічної колекції кафедри. Така система опорних конспектів до кожної лекції може використовуватись студентом як робочий зошит, своєрідний силабус для самопідготовки до лекції, написання реферату пропущеної лекції, а також доповнюватись під час конспектування лекції.

Лекторами кафедри анатомії людини створені також електронні бази навчального матеріалу до кожної тематичної лекції, які накопичені з різних науково-навчальних видань і постійно доповнюються. Така електронна лекційна база кафедри дозволяє кожному лектору, відповідно до теми лекції та її плану, творчо формувати і постійно вдосконалювати конкретний зміст лекцій та їі аудіовізуальне оснащення. Сучасні студенти, які достатньо володіють IT технологіями, налаштовані на емоційне, динамічне, візуалізоване сприйняття інформації. Саме тому сучасна лекція повинна бути ще більш змістовною, концентрованою, проблемно-орієнтованою та використовувати супровідний лекційний матеріал на основі мультимедійних технологій $[6,7]$. При цьому вдало підібрані слайди є своєрідними опорними сигналами, що сприяють формуванню просторового уявлення про будову органів і систем та супроводжуються на лекції подальшим деталізованим роз’ясненням у вигляді таблиць, графологічних зображень, усних формулювань тощо.

Структурування лекційного матеріалу на кафедрі анатомії людини відповідає сучасним методичним рекомендаціям до розробки лекційного заняття [4] і містить вступ, основну частину і висновки. У вступі лектор доводить до відома студентів мету лекції, її належне мотивування, повідомляє план лекції. Під час основного етапу у логічній послідовності викладається навчальний матеріал за темою лекції відповідно до плану та основних принципів дидактики вищої школи: науковості, зв’ язку теорії 3 практикою, систематичності та послідовності, а також забезпечується належне сучасне оснащення викладу слайдами, таблицями, малюнками, препаратами тощо. На заключному етапі лекції надаються відповіді на питання студентів, висновки та методичні настанови для вивчення навчального матеріалу на відповідних практичних заняттях та під час самостійної позааудиторної роботи.

На методичних стендах та web-сторінці кафедри розміщені плани до кожної лекції, перелік наукової та навчальної літератури для підготовки до лекції, а також написання студентами рефератів за матеріалами пропущених лекцій.

Висновки: 1. Сучасна анатомічна лекція є ареною реалізації найважливіших педагогічних категорій - виховання, освіти і навчання, а також важливим засобом формування корпоративної академічної культури університету, його іміджу перед студентською аудиторією.

2. Підбір фактичного матеріалу лекції, створення проблемних ситуацій, використання елементів інтерактивного навчання, мультимедійних технологій повинні здійснюватись лектором з урахуванням соціально-психологічного портрета сучасного студентства. 
3. Лекційний матеріал доцільно викладати з використанням принципів компетентнісного підходу і закладати підвалини формування компетенцій студентів у рамках викладання анатомії людини як фундаментальної природничо-наукової дисципліни.

4. У лекційному викладанні $є$ важливою присутність елементів контролю якості з навчальної дис-

\section{Список літератури}

1. Про вищу освіту : Закон України від 01.07.2014 р. № 1556-VII BP.

2. Довідник користувача Європейської кредитнотрансферної системи (ЄKTC) / [упоряд.: Т. В. Фініков та ін.] ; за ред. І. О. Вакарчука.-К., 2009.- 160 с.

3. Харгрейвз Кен. Підтримка навчання і викладання на сучасному медичному факультеті / Кен Харгрейвз, Єнн Марі Райд та Салія Мод ; пер. $з$ англ. - К. : Видавництво KIM, 2015.-197 c.

4. Максименко С. Д. Педагогіка вищої медичної освіти : підручник / С. Д. Максименко, М. М. Філоненко. - К. : Центр учбової літератури, 2014. - 288 с. ципліни через часткове інтерактивне опитування під час лекції, анкетування студентів, контроль викладачем академічної групи знань 3 лекційного матеріалу під час відповідних практичних занять.

5. Оптимальним у підготовці до лекцій є скерування студентів на офіційну web-сторінку кафедри з матеріалами до кожної анатомічної лекції.

5. Анатомія людини: підручник : у 3 т. / [А. С. Головацький, В. Г. Черкасов, М. Р. Сапін та ін.]. - Вінниця : Нова книга, 2015. - Т. 1. - 368 с. ; т. 2. - 456 с.; т. $3 .-376 \mathrm{c}$.

6. Столбова И. Д. Инновационные подходы к подготовке лекционного материала / И. Д. Столбова, Е. С. Дударь // Alma mater. Вестник высшей школы. 2008. - № 6. - С. 29-35.

7. Князевич-Чорна Т. В. Особлива роль лекції при викладанні теоретичних дисциплін студентам-іноземцям / Т. В. Князевич-Чорна // Галицький лікарський вісник. - 2013. - T. 2.- C. 104-105. 